\title{
əEstimating the Velocity and Transport of Western Boundary Current Systems: A Case Study of the East Australian Current near Brisbane
}

\author{
N. V. Zilberman, D. H. Roemmich, S. T. Gille, AND J. Gilson \\ Scripps Institution of Oceanography, University of California, San Diego, La Jolla, California
}

(Manuscript received 6 September 2017, in final form 7 March 2018)

\begin{abstract}
Western boundary currents (WBCs) are highly variable narrow meandering jets, making assessment of their volume transports a complex task. The required high-resolution temporal and spatial measurements are available only at a limited number of sites. In this study a method is developed for improving estimates of the East Australian Current (EAC) mean transport and its low-frequency variability, using complementary modern datasets. The present calculation is a case study that will be extended to other subtropical WBCs. The method developed in this work will reduce uncertainties in estimates of the WBC volume transport and in the interannual mass and heat budgets of the meridional overturning circulations, improving our understanding of the response of WBCs to local and remote forcing on long time scales. High-resolution expendable bathythermograph (HR-XBT) profiles collected along a transect crossing the EAC system near Brisbane, Australia, are merged with coexisting profiles and parking-depth trajectories from Argo floats, and with altimetric sea surface height data. Using HR-XBT/Argo/altimetry data combined with Argo trajectorybased velocities at $1000 \mathrm{~m}$, the 2004-15 mean poleward alongshore transport of the EAC is $19.5 \pm 2.0 \mathrm{~Sv}$ $\left(1 \mathrm{~Sv} \equiv 10^{6} \mathrm{~m}^{3} \mathrm{~s}^{-1}\right)$ of which $2.5 \pm 0.5 \mathrm{~Sv}$ recirculate equatorward just offshore of the EAC. These transport estimates are consistent in their mean and variability with concurrent and nearly collocated moored observations at $27^{\circ} \mathrm{S}$, and with earlier moored observations along $30^{\circ} \mathrm{S}$. Geostrophic transport anomalies in the EAC system, including the EAC recirculation, show a standard deviation of $\pm 3.1 \mathrm{~Sv}$ at interannual time scales between 2004 and 2015.
\end{abstract}

\section{Introduction}

Western boundary currents (WBCs) represent the primary route for the export of tropical water masses from low to midlatitudes, including elements of the shallow meridional overturning circulations (Talley 2008; Huang 2010). The strength and variability of WBCs affect air-sea fluxes of heat and moisture and influence storm-track evolution and extreme weather event frequency in WBC regions (Cai et al. 2012). WBCs and recirculation are not well represented in coupled climate models. Numerical predictions of WBC variability present large uncertainties (Kwon et al. 2010). A better understanding of how climate change is affecting the transports of heat and freshwater in WBC regions calls for new observational studies of sustained duration (Hu et al. 2015). Observational arrays specifically

¿ Denotes content that is immediately available upon publication as open access.

Corresponding author: N. V. Zilberman, nzilberman@ucsd.edu designed to study WBCs have been few in number and of limited duration. The aim of this work is to develop an accurate method for estimating long-term time series of transport in the subtropical WBCs of the Pacific, Atlantic, and Indian Oceans based on sustained ocean observations.

Calculating WBC transport is a challenging task for several reasons. WBCs are confined to a width of about $100 \mathrm{~km}$ and are generally accompanied by recirculation gyres and energetic eddy fields, making for an interconnected dynamic system (Kang and Curchitser 2013). WBCs have large vertical extent typically requiring ocean measurements to greater than 1000-m depth, and in some cases they penetrate to the ocean bottom (Beal et al. 2006). The strength of WBCs, their offshore edge, and their meandering change on seasonal to decadal time scales (Sloyan et al. 2016). One major difficulty is to obtain observations with sufficiently fine resolution to resolve the flow field in space and time along the narrow path of the WBCs (Mata et al. 2000). The spatial resolution requirements are made more challenging by the need for transport arrays to fully span WBCs 
during offshore meander events. Because of the inherent properties of WBCs, estimation of WBC velocity and transport places heavy demands on any potential sampling scheme. Modeling and data analyses have emphasized the large uncertainties in WBC transport estimates (e.g., Hu et al. 2015). One strategy for studying WBCs is to combine complementary data sources.

The high-resolution expendable bathythermograph (HR-XBT) network is the only element of the sustained ocean observing system that provides regular observations in all five subtropical WBCs while resolving their across-stream structure. After beginning with a single transect in 1986, the HR-XBT network expanded during the World Ocean Circulation Experiment to include coast-to-coast transects in all the oceans, usually on a quarterly basis. Many of these transects are continued today (e.g., Goni et al. 2010), having produced a 25-yr time series. Temperature profiles from the sea surface to about 800-m depth are collected using XBT probes deployed from commercial ships. The high-speed core of the WBCs is typically shallower than $800 \mathrm{~m}$ (Yang et al. 2015; Schönau et al. 2015). In some cases, their signature extends to greater depth (Zilberman et al. 2014; Meinen and Luther 2016; Beal and Elipot 2016). Some WBCs are accompanied by undercurrents flowing in the opposite directions (Sloyan et al. 2016; Lien et al. 2015). For this reason, HR-XBT measurements alone miss a significant portion of WBC transport. The Argo array provides temperature and salinity profiles between 2000 dbar and the ocean surface, as well as trajectories at the Argo parking depth, typically 1000 dbar (Ollitrault and Rannou 2013). Since the end of 2007, the Argo program has reached its target of a sustained array of 3300 floats, providing roughly $3^{\circ} \times 3^{\circ} \times 10$-day sampling globally (Riser et al. 2016). Outside of coastal zones and sea ice-covered areas, the Argo fleet can resolve largescale features on seasonal and longer time scales. Argo coverage provides accurate estimates of the mean temperature and salinity fields in the upper- 2000 dbar along with trajectory-based velocities at parking pressure. On a regional basis, year-to-year sampling varies depending on the research vessels and ships of opportunity available to deploy Argo floats, the exact positions of float deployments, and the float redistribution by ocean currents. In general, Argo data coverage is not dense enough to estimate synoptic WBC transport. In contrast, moored arrays offer the advantage of providing continuous time series of top-to-bottom ocean currents and water properties at fixed locations, and they represent the state of the art in WBC transport observation. Moored arrays are expensive, both in terms of the ship time needed for deployment and recovery and the requirements for fine spatial resolution for accurate estimates of WBC transport. Because of their cost, longduration moored arrays spanning WBCs have been limited to isolated areas, and in some cases they do not extend far enough offshore to observe the meandering WBC signature (e.g., Mata et al. 2000; Send et al. 2010).

The East Australian Current (EAC) is a well-studied WBC that constitutes the principal southward limb of the South Pacific subtropical gyre. This current originates from the southward branch of the South Equatorial Current bifurcation at the northeast coast of Australia. It flows along the Australian continental slope to about $32^{\circ} \mathrm{S}$, where it separates into the Tasman Front (TF), extending eastward across the Tasman Sea, and the EAC extension $\left(\mathrm{EAC}_{\mathrm{ex}}\right)$, flowing farther southward (Tilburg et al. 2001). The EAC system is associated with northward recirculation gyres, constrained by the bathymetry, that are located offshore of a $150-\mathrm{km}$ wide southward jet (Ridgway and Dunn 2003). The EAC transport is $22.1 \pm 7.5 \mathrm{~Sv}\left(1 \mathrm{~Sv} \equiv 10^{6} \mathrm{~m}^{3} \mathrm{~s}^{-1}\right)$ at $27^{\circ} \mathrm{S}$, has a similar magnitude at $30^{\circ} \mathrm{S}$, and strengthens to $23.3 \pm 2.9 \mathrm{~Sv}$ at $32^{\circ} \mathrm{S}$ (Mata et al. 2000; Zilberman et al. 2014; Sloyan et al. 2016). In this latitude range, the core of the EAC is located $50 \mathrm{~km}$ offshore from the coast (Archer et al. 2017).

The objective of the present study is to provide a method for long-term estimation of the EAC and recirculation transports near Brisbane, Australia, based on the HR-XBT network, the Argo array, and altimetric datasets. These transport estimates are compared with moored observations described by Sloyan et al. (2016), spanning the EAC off Brisbane at approximately $27^{\circ} \mathrm{S}$, between April 2012 and August 2013 (Fig. 1). Additional comparisons are made using velocity and transport estimates from a moored array at $30^{\circ} \mathrm{S}$, between 1992 and 1993, as part of the World Ocean Circulation Experiment (Mata et al. 2000). The work is organized as follows. The data and methods are presented in section 2. Estimates of the mean EAC transport across XBT line PX30 are calculated, and results for the interannual variability of the EAC transport are discussed in section 3. A summary and conclusions are presented in section 4. This work is a case study of the capabilities of integrated ocean observations for boundary current estimation and for addressing climate-related variability in the western boundary region.

\section{Method}

A methodology for estimating absolute geostrophic velocity and transport in the EAC region near Brisbane is developed. Argo temperature and salinity profiles are used first for estimation of salinity from HR-XBT temperature profiles, second for horizontal interpolation of 


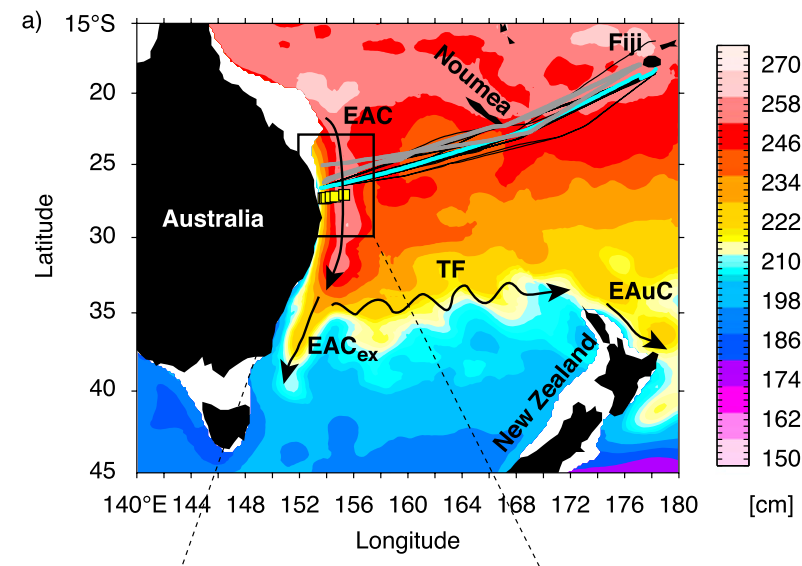

b)

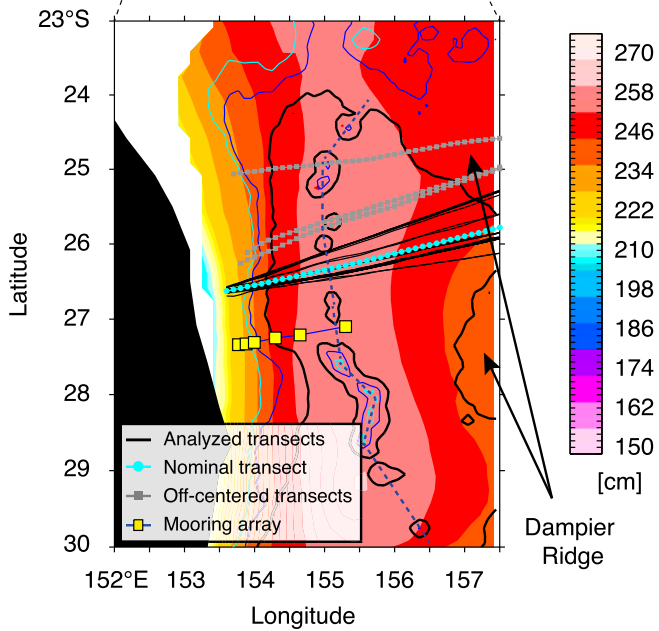

FIG. 1. Schematic of the EAC, $\mathrm{EAC}_{\mathrm{ex}}$, TF, and EAuC. The underlying color gives the steric height at the sea surface relative to $1975 \mathrm{~m}$ averaged between 2004 and 2015, computed using the gridded Argo climatology data described in section 2a(2), in (a) the southwestern Pacific and (b) the EAC region near Brisbane. The PX30 transects between 2004 and 2015 used for analysis (black lines). The time-averaged PX30 route, called nominal transect (round light-blue circles). PX30 routes off centered from the nominal transect (square gray symbols). Contours in (b) indicate depths (m) of 1000 (light blue), 2000 (dark blue), and 4000 (thick black). Indicated with square yellow symbols are locations of the moorings from Sloyan et al. (2016). The Dampier Ridge is shown with black arrows and the Tasmantid Seamount chain (dashed blue line; Van der Linden 1970).

HR-XBT temperature and salinity onto the 2004-15 mean PX30 route, and third to extend dynamic height and geostrophic shear estimation to $1975 \mathrm{~m}$. Reference velocities at Argo's 1000-dbar parking depth are estimated from Argo float trajectories and are used to convert the mean shear estimates to absolute velocity. Finally, the XBT/Argo data are merged with satellite altimetric observations of sea surface height, using a simple linear regression, to estimate interannual variability in dynamic height. a. Data

\section{1) HR-XBT}

HR-XBT observations collected along line PX30, from Fiji to Brisbane, provide high-spatial-resolution temperature profiles between the sea surface and about $800 \mathrm{~m}$. The HR-XBT data, obtained through a partnership of the Commonwealth Scientific and Industrial Research Organisation (CSIRO) and the Scripps Institution of Oceanography, are made freely available (http://www-hrx.ucsd.edu). HR-XBT sampling has been carried out along this line, at approximately $26.5^{\circ} \mathrm{S}$ near the Brisbane end, nominally on a quarterly basis since 1991 (Goni et al. 2010). For combining with Argo temperature and salinity profiles and trajectory data, we will focus on HR-XBT profiles collected between 2004 and 2015. HR-XBT profiles are collected using Sippican Deep Blue XBT probes dropped at $32-35-\mathrm{km}$ intervals between $157^{\circ}$ and $159^{\circ} \mathrm{E}$, decreasing to $25-\mathrm{km}$ intervals between $155^{\circ}$ and $157^{\circ} \mathrm{E}$, and $8-10-\mathrm{km}$ intervals between $155^{\circ} \mathrm{E}$ and the Australian coast. Transects in November 2011, May 2012, and June 2013 (square gray symbols in Fig. 1) deviated from the PX30 mean 2004-15 route (light-blue circles in Fig. 1), and profiles from these months are not included in our calculations. Estimates of geostrophic velocity and transport are computed between $153.5^{\circ} \mathrm{E}$, which is the inshore limit of the PX30 nominal transect, and $157.5^{\circ} \mathrm{E}$, which is the offshore edge of the 2004-15 mean EAC recirculation (see section 3). A total of $40 \mathrm{HR}-\mathrm{XBT}$ transects (black lines in Fig. 1), including 1142 XBT profiles collected between $153.5^{\circ}$ and $157.5^{\circ} \mathrm{E}$, are analyzed (Table 1 ). Sippican Deep Blue XBT probes are rated to $760-\mathrm{m}$ depth. To maximize data quality, here we focus on HR-XBT profiles within $0-760 \mathrm{~m}$.

Instrumental errors in HR-XBT measurements are largely due to depth estimation based on fall-rate equations (FRE). The depth in HR-XBT data is not directly measured but is estimated empirically based on the measured fall rate of the XBT probe (Hanawa et al. 1995). Probe-to-probe random depth errors caused by variability in the fall rate are about $2 \%$ of the depth. Coefficients for the FRE are provided by the manufacturer, but these have been shown to have systematic errors that may vary from year to year (Levitus et al. 2009). The XBT community recommends using FRE corrections for improving data quality (Cheng et al. 2016). Here, FRE are corrected using Cowley et al.'s (2013) corrections for Deep Blue Sippican profiles. These parameters, for probes manufactured in 2004-12, are provided by the National Oceanographic Data Center (https://www.nodc.noaa.gov/OC5/XBT_BIAS/cowley.html). 
TABLE 1. Sampling time near Brisbane along PX30 between 2004 and 2015. Out of 43 transects sampled, 40 were used in our calculations (check marks) and 3 were omitted from our analysis because of anomalous ship routing (cross signs).

\begin{tabular}{|c|c|c|c|c|c|c|c|c|c|c|c|c|}
\hline & Jan & $\mathrm{Feb}$ & Mar & Apr & May & Jun & $\mathrm{Jul}$ & Aug & Sep & Oct & Nov & $\overline{D e c}$ \\
\hline 2004 & 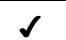 & & 4 & & & $\checkmark$ & & & $\sqrt{2}$ & & & $\checkmark$ \\
\hline 2005 & & & & $\checkmark$ & & & $\checkmark$ & & & $\checkmark$ & & $\checkmark$ \\
\hline 2006 & & & & $\checkmark$ & & $\checkmark$ & & & $\checkmark$ & & & \\
\hline 2007 & & $\checkmark$ & & & $\checkmark$ & & $\checkmark$ & & & & $\checkmark$ & \\
\hline 2008 & & $\checkmark$ & & & $\checkmark$ & & & $\checkmark$ & & & $\checkmark$ & \\
\hline 2009 & & $\checkmark$ & & & $\checkmark$ & & & $\checkmark$ & & & $\checkmark$ & \\
\hline 2010 & & $\checkmark$ & & & $\checkmark$ & & $\checkmark$ & & & $\checkmark$ & & \\
\hline 2011 & & $\checkmark$ & & $\checkmark$ & & & & & & & $x$ & \\
\hline 2012 & & & $\checkmark$ & & $x$ & & & & $\checkmark$ & & & \\
\hline 2013 & & & & & & $x$ & & & & $\checkmark$ & & \\
\hline 2014 & & $\checkmark$ & & & $\checkmark$ & & & & & & $\checkmark$ & \\
\hline 2015 & & $\checkmark$ & & & $\checkmark$ & & & $\checkmark$ & & & $\checkmark$ & \\
\hline
\end{tabular}

Corrections for 2013-15 are made using the parameters from 2012 (R. Cowley 2017, personal communication). Temperature bias after depth correction is small for Sippican Deep Blue manufactured between 2004 and 2012 (Cowley et al. 2013). In any case, XBT fall-rate errors and temperature bias that are uniform across a transect have little effect on estimated geostrophic shear.

\section{2) Argo profiles And Argo floht TRAJECTORIES}

Argo temperature and salinity profiles collected between January 2004 and December 2015, provided by the Argo Global Data Assembly Centers (http://www. argodatamgt.org), are used to compute salinity fields to be combined with HR-XBT temperature (see the appendix), and also to extend density and steric height (SH) estimates for each transect below the XBT depth range. Argo trajectory-based velocities at the parking depth, from 2004 to 2015, provide reference velocity for absolute velocity estimates. Argo float parking pressure may vary from its programmed value depending on pumping consistency between cycles, efficiency to reach target pressure, and modified buoyancy. The typical variation of Argo float parking pressure is 9001100 dbar for $76 \%$ of the Argo floats currently active. A correction based on the geostrophic shear can be applied to account for changes in parking depth (Gray and Riser 2014; Gille 2003). For this analysis, Argo float trajectories are used only if the floats park at pressure between 900 and $1100 \mathrm{dbar}$. The averaged value of parking pressure is $1003 \mathrm{dbar}$, and the standard deviation is $\pm 10.1 \mathrm{dbar}$. The vertical shear in horizontal velocity between $1000 \mathrm{~m}$ and parking depth generates small $\left(<1 \times 10^{-4} \mathrm{~m} \mathrm{~s}^{-1}\right)$ changes in horizontal velocities at $1000 \mathrm{~m}$, and for that reason is not considered further here. Argo floats used in this study include 48 floats equipped with Argos telemetry and 7 with Iridium (Riser et al. 2016). The float drift at parking depth is calculated using the method described by Zilberman et al. (2017).

The continental slope and shelf boundaries exert a strong influence on the orientation of the flow in the EAC (Ridgway and Dunn 2003). Trajectory-based velocities for $2004-15$ are sorted into $1 / 6^{\circ}$ latitude $\times 1 / 2^{\circ}$ longitude bins aligned with the $1000-\mathrm{m}$ isobaths to account for longitudinal offsets and to preserve the alongtopography orientation of the transport. Year-to-year Argo sampling varies considerably between 2004 and 2015 (Figs. 2a-d). To increase the number of velocity observations per bin, the $\left(1 / 6^{\circ} \times 1 / 2^{\circ}\right)$ bins are grouped and the trajectory data are averaged into $3^{\circ}$ latitude $\times 1 / 2^{\circ}$ longitude grid cells centered along the PX30 mean $2004-15$ route. The number of Argo profiles per $\left(3^{\circ} \times 1 / 2^{\circ}\right)$ bin is 8 on the continental slope, at the inshore edge of the EAC, increasing to 44-72 profiles per bin between $154^{\circ}$ and $158^{\circ} \mathrm{E}$ (Fig. 3). A total of 478 Argo profiles are analyzed. The Argo community envisions doubling the spatial coverage of Argo float profiles in western boundary current regions (Roemmich et al. 2010).

A high-resolution temporal mean Argo product is used to project HR-XBT temperature and derived salinity profiles along each transect onto the PX30 nominal route (see section 2b), and to calculate Argo-only velocity estimates (see section 3 ). The high-resolution Argo climatology is constructed using a least squares fit of 33 neighboring Argo temperature and salinity profiles collected between 2004 and 2015, and mapped to a $1 / 6^{\circ} \times 1 / 6^{\circ}$ grid. The mapping of Argo profiles is described by Roemmich and Gilson (2009).

\section{3) Altimetric dataset}

Satellite altimetry products are complementary to hydrographic data for studying the time variability of 

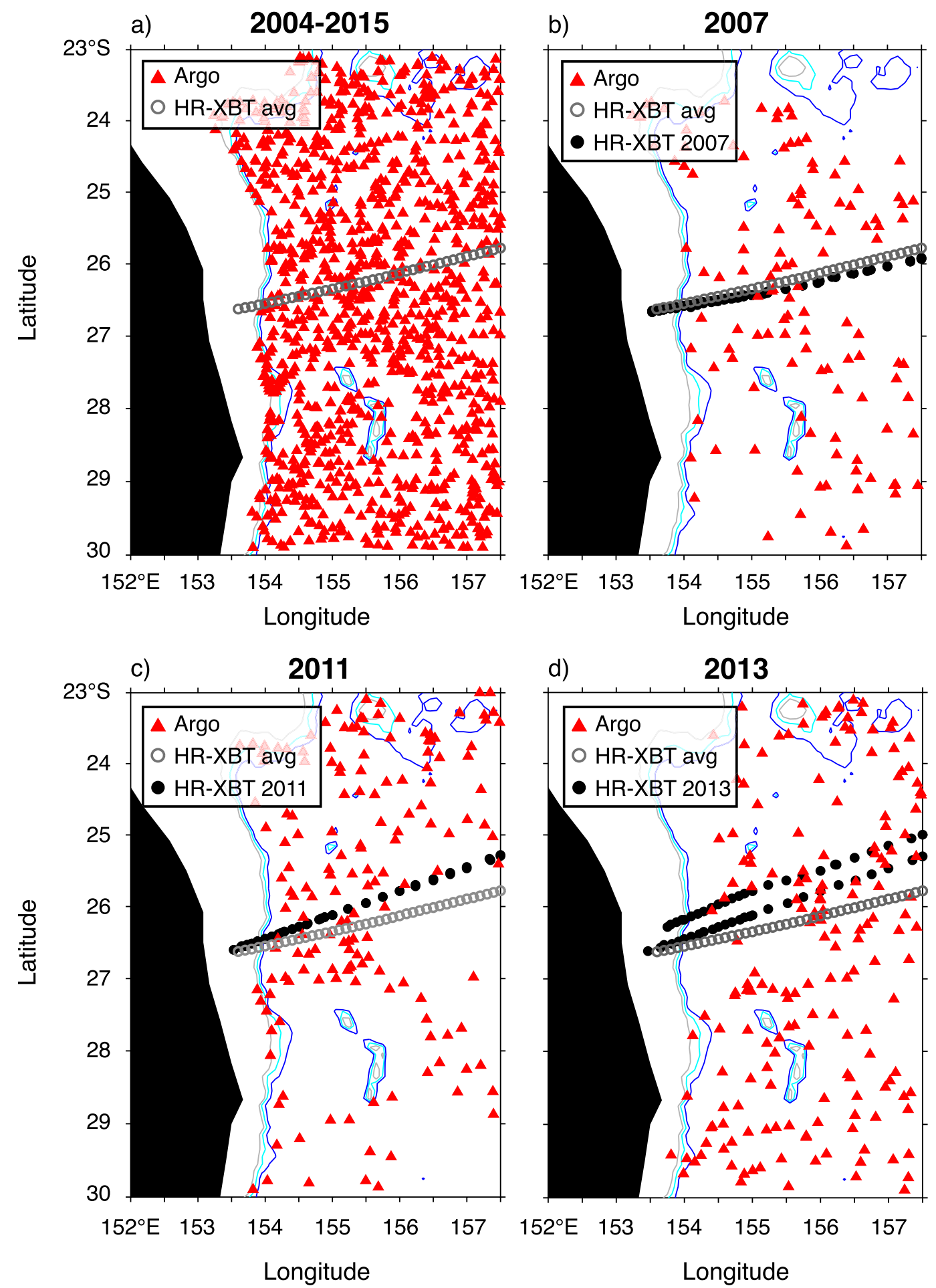

d)

2013

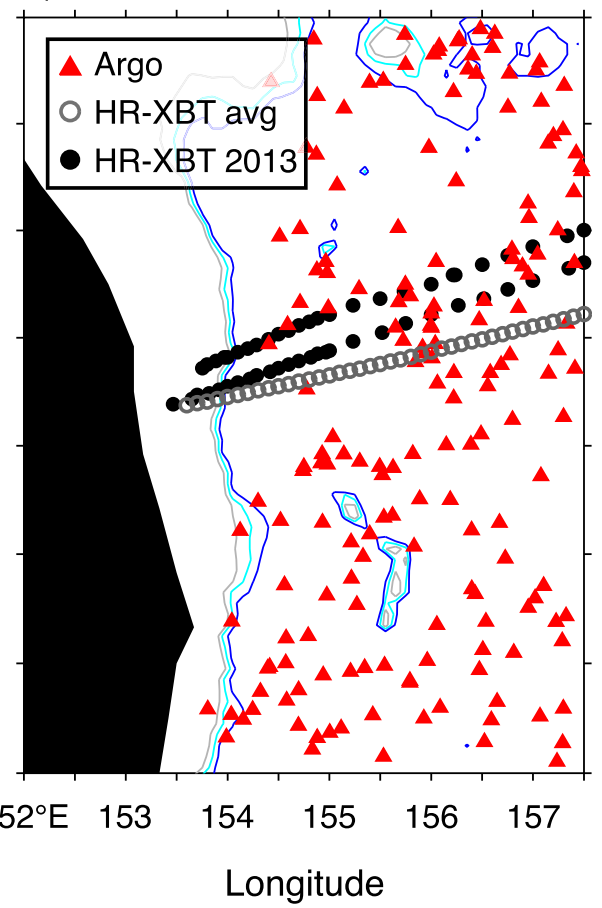

FIG. 2. Map of Argo float observations (red triangle symbols) (a) between 2004 and 2015, and in (b) 2007, (c) 2011, and (d) 2013. The 2004-15 averaged PX30 nominal transect is indicated with round gray symbols. Routes of PX30 in 2007, 2011, and 2013 are indicated with round black symbols. Contours indicate depths (m) of 1000 (gray), 1500 (light blue), and 2000 (dark blue). 


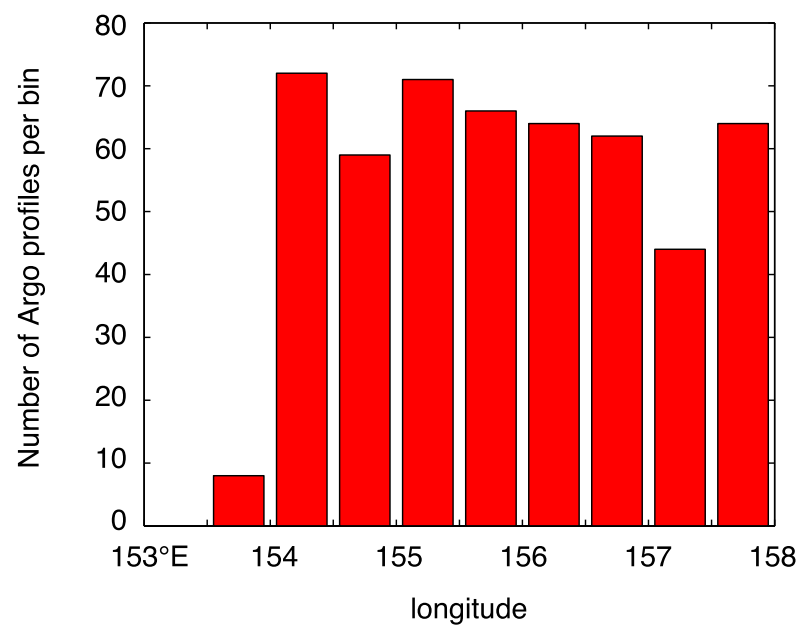

FIG. 3. Number of Argo trajectory-based velocity observations per $3^{\circ}$ latitude $\times 1 / 2^{\circ}$ longitude grid cells centered along the PX30 nominal transect between 2004 and 2015.

the geostrophic velocity and transport of WBCs (Imawaki et al. 2001; Ridgway et al. 2008). The SSALTO/Data Unification and Altimeter Combination System (DUACS) fields used here are monthly means of delayed-time daily fields of altimetric sea surface height $(\mathrm{SSH})$ anomaly projected onto a $1 / 4^{\circ} \times 1 / 4^{\circ}$ grid (ftp:// ftpsedr.cls.fr/pub/oceano/AVISO/SSH/duacs/Data_Test/ global/delayed-time/grids/msla/two-sat-merged). The altimetry fields were adjusted to represent anomalies relative to a 2004-15 mean for consistency with the Argo dataset.

\section{b. Computational approach}

Because of changes in ships used, and their routing, the latitudes of HR-XBT stations at a fixed longitude vary between PX30 transects (black lines in Fig. 1). Averaging HR-XBT profiles from all transects for a given longitude attenuates horizontal density gradients and therefore reduces the magnitudes of the EAC and recirculation (not shown). Instead, HR-XBT temperature and salinity profiles along each track are projected onto a nominal transect, defined as the 2004-15 mean route of PX30 (light-blue circles in Fig. 1), using horizontal gradients of temperature and salinity from highresolution gridded Argo climatology of 2004-15. The along-track spacing of the derived temperature and salinity on the nominal transect is $10 \mathrm{~km}$. Raw Argo profiles between $25^{\circ}-27^{\circ} \mathrm{S}$ and $153^{\circ}-158^{\circ} \mathrm{E}$ from 2004 to 2015 show SH values relative to $1975 \mathrm{~m}$ that are strongly correlated with the temperature at $760 \mathrm{~m}$ (not shown). The correlation coefficient $(R)$ between the Argo SH relative to $1975 \mathrm{~m}$ and the temperature at $760 \mathrm{~m}$ is high $(>0.7)$ between $1200 \mathrm{~m}$ and the sea surface, and shows
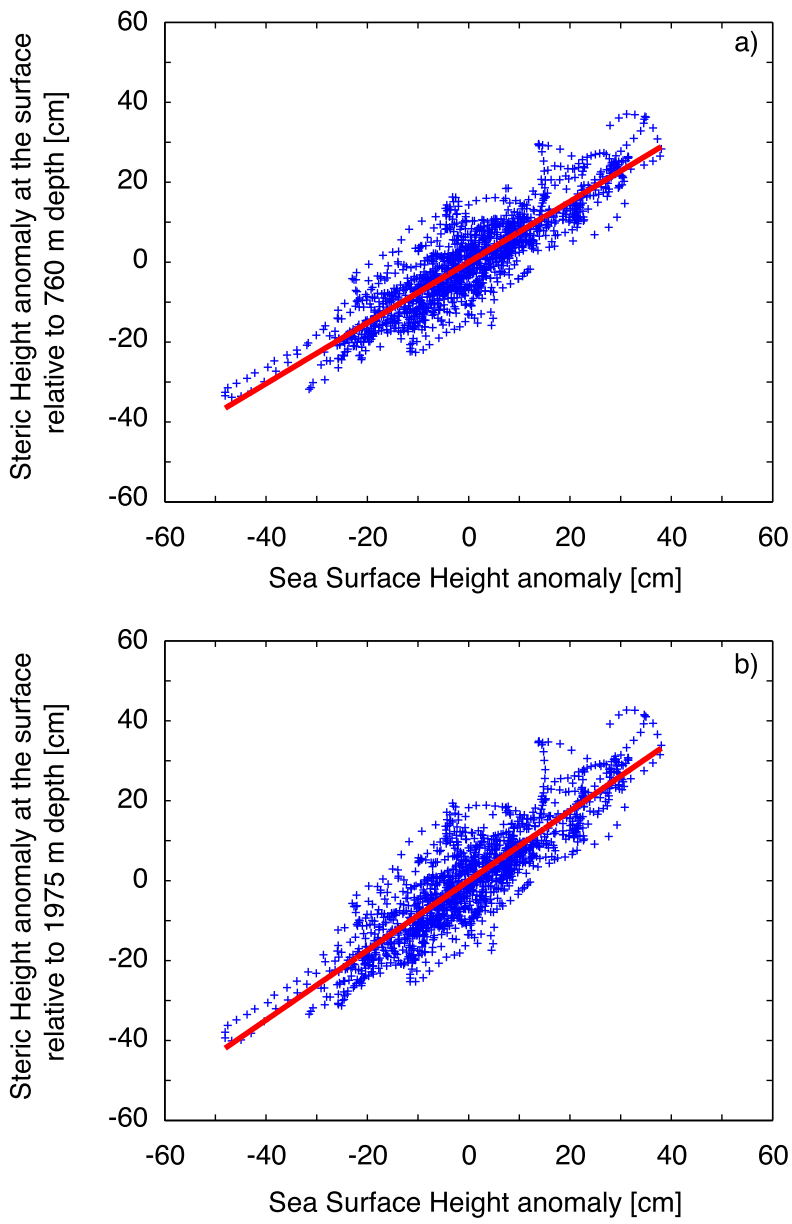

FIG. 4. HR-XBT/Argo-based SH anomalies at the sea surface relative to (a) 760-m depth, and (b) 1975-m depth, plotted against Aviso-based SSH anomalies interpolated at each HR-XBT profile location for all transects between 2004 and 2015. The linear fit is indicated (red line).

moderate values of $0.45-0.7$ below $1200 \mathrm{~m}$. Following Ridgway and Godfrey (1997), their Eq. (1), estimates of instantaneous HR-XBT/Argo SH at depth $z$, relative to $1975 \mathrm{~m}$, are calculated as

$$
\begin{aligned}
h(z / 1975)= & h(z / 760)+\alpha_{\mathrm{Argo}}(760) T_{760} \\
& +\beta_{\mathrm{Argo}}(760) \quad z<760 \mathrm{~m}, \\
h(z / 1975)= & \alpha_{\mathrm{Argo}}(z) T_{760}+\beta_{\mathrm{Argo}}(z) \quad 760<z<1975 \mathrm{~m},
\end{aligned}
$$

where $h(z / 760)$ is HR-XBT SH at depth $z$, relative to $760 \mathrm{~m} ; \alpha_{\text {Argo }}$ and $\beta_{\text {Argo }}$ are best-fit functions between SH relative to $1975 \mathrm{~m}$ and temperature values at $760 \mathrm{~m}$ based on raw Argo profiles between $25^{\circ}-27^{\circ} \mathrm{S}$ and $153^{\circ}-$ $158^{\circ} \mathrm{E}$ from 2004 to 2015 ; and $T_{760}$ is the HR-XBT temperature at $760 \mathrm{~m}$. 
According to the moored array observations by Sloyan et al. (2016), the position and strength of both the EAC and the northward recirculation show significant variability at $1-2$-month time scales at $27^{\circ} \mathrm{S}$. Combining HR-XBT/Argo SH anomalies with altimetry can mitigate temporal aliasing by the HR-XBT transects and reduce sampling errors in the HR-XBT/ Argo datasets (Ridgway and Dunn 2010). Here, SSH anomalies are merged with HR-XBT/Argo data to compute monthly means of geostrophic velocity and to describe the interannual variability of the EAC transport shown in section 3 . The standard error of the mean EAC transport based on the monthly values of 2004-15 is half the error of the transport using estimates from all HR-XBT transects rather than the monthly HR-XBT/ altimetry estimates. Figures $4 \mathrm{a}$ and $4 \mathrm{~b}$ show anomalies of weekly mean SSH plotted against $\mathrm{SH}$ anomalies relative to 760 and $1975 \mathrm{~m}$, respectively, for all transects. Results indicate that SSH anomalies are strongly correlated with SH anomalies. The correlation coefficient between SSH and $\mathrm{SH}$ anomalies is 0.88 , and the best-fit slope of $\mathrm{SH}$ anomalies versus SSH anomalies is $0.87 \pm 0.01$ when using a reference level for $\mathrm{SH}$ at $1975 \mathrm{~m}$. This indicates that the geostrophic flow variability over the depth range $0-1975 \mathrm{~m}$ is mostly upper-ocean steric in nature.

Here, monthly anomalies of SH from 2004 to 2015 based on HR-XBT, Argo, and altimetry (HR-XBT/ Argo/altimetry) are computed as

$$
d h(z, 1975)=a(z) d H_{a}+b+\varepsilon,
$$

where $d H_{a}$ are monthly SSH anomalies from SSALTO/ DUACS interpolated onto the PX30 nominal transect; $a(z)$ is the best-fit function between SSALTO/DUACS SSH and HR-XBT/Argo SH anomalies for all transects; $b$ is the intercept; and $\varepsilon$ is the error of the linear fit between the SSH and SH anomalies, which includes a combination of altimeter instrumental and interpolation error, and the error generated by changes in ocean mass, and variations in ocean density below $1975 \mathrm{~m}$. The linear fit between the SSH and SH anomalies is shown by the red line in Fig. 4.

We compute the monthly mean component of the absolute geostrophic velocity normal to the PX30 nominal track:

$$
V(z, x)=v(z / 1975, x)-\overline{v(1000 / 1975, x)}+\overline{v_{\text {traj }}(x)},
$$

where $v(z / 1975, x)=-1 / f[\partial h(z / 1975, x) / \partial x]$ is the monthly mean geostrophic velocity at depth $z$ relative to $1975 \mathrm{~m}$, the differential of SH is between cells $(x+1)$ and $(x-1)$, $f$ is the Coriolis parameter, the overbar indicates an average between 2004 and $2015, v(1000 / 1975, x)$ is the velocity at $1000 \mathrm{~m}$ relative to $1975 \mathrm{~m}$, and $v_{\text {traj }}(x)$ is the trajectory-based velocity at $1000 \mathrm{~m}$. The Argo float is displaced horizontally during the rise and fall between the surface and the parking depth. The shearinduced error is removed from the absolute transport assuming that the float ascending and descending times represent $5 \%$ of each cycle (Zilberman et al. 2014).

Absolute geostrophic velocities are calculated relative to the bottom in regions shallower than $1000 \mathrm{~m}$. The bottom topography used here is from the ETOPO2 dataset (Smith and Sandwell 1997). For comparison, we also calculate geostrophic velocities based on Argo-only datasets, including high-resolution gridded Argo mean fields of temperature and salinity for the January 2004December 2015 period, and bin-averaged trajectorybased velocities [described in section $2 \mathrm{a}(2)$ ].

Geostrophic velocity and resulting transport estimates are presented in the next section. Uncertainties in estimates of the 2004-15 mean volume transport computed using HR-XBT and Argo datasets are assigned based on the standard error, which is the standard deviation of trajectory-based velocities divided by the square root of the number of observations per $\left(3^{\circ} \times 1 / 2^{\circ}\right)$ bin used for analysis. In other words, the somewhat noisy trajectory dataset is assumed to dominate the transport error budget. The quality of the Argo dataset in WBC regions is an important topic. The transport in the EAC system inferred after removing half of the Argo float trajectory data per bin is $12 \%$ higher, but it is not significantly different from results using all data available. Some WBCs are as well as or better sampled than the EAC (e.g., Kuroshio). The quality of the volume transport estimates in all WBCs will improve as the Argo dataset expands.

\section{Results and discussion}

Estimates of geostrophic velocities and transports for flow across the PX30 nominal transect, computed using HR-XBT, Argo, and altimetric datasets, are compared with Argo-only data and independent moored observations at nearby locations. Time series showing the interannual variability of the transport in the EAC and recirculation are presented.

\section{a. Geostrophic velocity and transport averaged between 2004 and 2015}

\section{1) ESTIMATES BETWEEN $760 \mathrm{M}$ AND THE SEA SURFACE}

Geostrophic velocities relative to $760 \mathrm{~m}$, based on instantaneous HR-XBT temperature and inferred salinity profiles (HR-XBT/Argo), are projected onto the PX30 

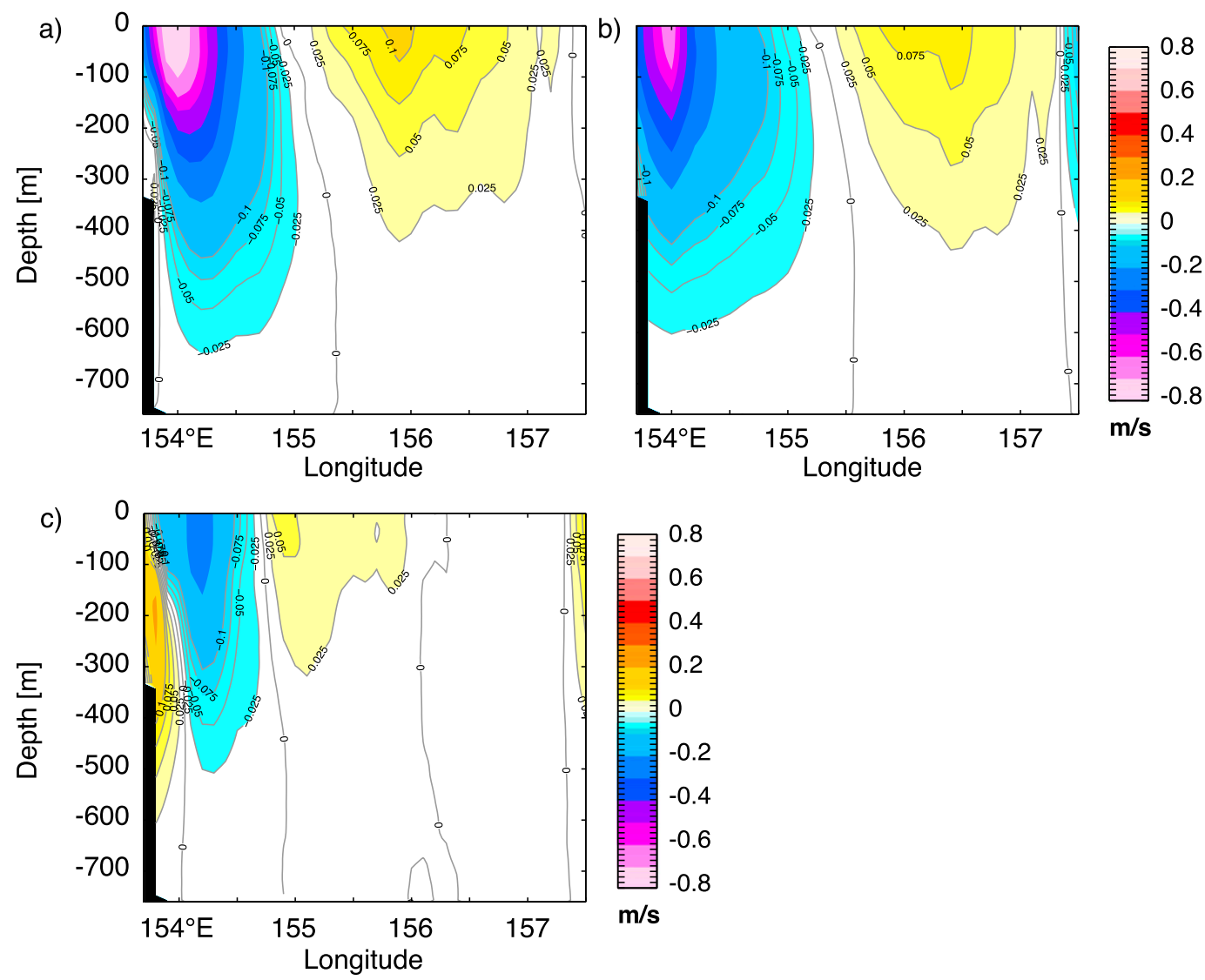

FIG. 5. Geostrophic velocity relative to $760 \mathrm{~m}$ normal to the PX30 nominal track, using (a) HR-XBT/Argo and (b) Argo-only data, averaged between 2004 and 2015. (c) Difference between geostrophic velocity estimates computed using HR-XBT/Argo and Argo-only data. Contour intervals are $0.1 \mathrm{~m} \mathrm{~s}^{-1}$ for velocities higher than $0.1 \mathrm{~m} \mathrm{~s}^{-1}$ and lower than $-0.1 \mathrm{~m} \mathrm{~s}^{-1}$, and $0.025 \mathrm{~m} \mathrm{~s}^{-1}$ for velocities from -0.1 to $0.1 \mathrm{~m} \mathrm{~s}^{-1}$. The zero velocity contour is indicated.

nominal transect. The mean velocity field normal to the transect, averaged between 2004 and 2015, is presented in Fig. 5a. Southward (negative) velocities above 760-m depth, between the continental shelf and $155.1^{\circ} \mathrm{E}$, are indicative of the EAC. Southward velocities are strongest $\left(<-0.4 \mathrm{~m} \mathrm{~s}^{-1}\right)$ at the core of the EAC, between $200 \mathrm{~m}$ and the sea surface. East of $155.1^{\circ} \mathrm{E}$, moderate $\left(0.025 \mathrm{~m} \mathrm{~s}^{-1}\right)$ northward velocities above 400-m depth are consistent with the EAC recirculation signature (Ridgway and Dunn. 2003). Geostrophic velocity estimates derived using highresolution gridded Argo data (Argo only), averaged between 2004 and 2015, show good agreement with merged HR-XBT/Argo (Figs. 5a,b). Small discrepancies are observed in the EAC and recirculation regions. Velocities at the core of the EAC are $0.1-0.2 \mathrm{~m} \mathrm{~s}^{-1}$ higher, and velocity gradients at the offshore edge of the EAC are sharper using HR-XBT/Argo compared to Argo-only data. Velocities using HR-XBT/Argo near the sea surface in the EAC recirculation are $0.025 \mathrm{~m} \mathrm{~s}^{-1}$ higher than those from the Argo-only dataset. The discrepancies seen between the two products are largely due to the small number of Argo profiles, resulting in a smoother velocity field, effectively having lower resolution than that of the HR-XBT transects.

Estimates of 2004-15 mean geostrophic transports relative to $760 \mathrm{~m}$, integrated between $760-\mathrm{m}$ depth and the sea surface, and accumulated eastward are presented in Fig. 6. The EAC mean transport is defined here as the maximum southward transport integrated eastward. HR-XBT/Argo-based EAC relative transport (blue line, $0-760$ relative to $760 \mathrm{~m}$ ) is $13.3 \pm 0.8 \mathrm{~Sv}$ west of $155.1^{\circ} \mathrm{E}$, of which $3.9 \pm 0.2 \mathrm{~Sv}$ recirculate northward between $155.1^{\circ}$ and $157.5^{\circ} \mathrm{E}$. The offshore limit of the EAC in the Argo-only calculation is $155.4^{\circ} \mathrm{E}$, located $31 \mathrm{~km}$ farther off the coast than estimated using HR-XBT/ Argo. Transport values derived using Argo-only data (black line) are $12.0 \pm 0.8 \mathrm{~Sv}$ southward in the EAC and $3.3 \pm 0.2 \mathrm{~Sv}$ northward in the EAC recirculation. The net volume transport, including EAC and recirculation, integrated along the nominal transect is $8.7 \pm 1.0 \mathrm{~Sv}$ 
southward using Argo-only data, consistent with HRXBT/Argo (Fig. 6).

\section{2) Estimates BeTWeEN 1975 M AND THE SEA SURFACE}

Instantaneous geostrophic velocities derived using HR-XBT/Argo are extended to $1975 \mathrm{~m}$ and combined with altimetry to calculate monthly values of velocity and transport from 2004 to 2015 . The method used for combining HR-XBT, Argo, and altimetry data is described in section $2 \mathrm{~b}$. Absolute velocity estimates between $1975 \mathrm{~m}$ and the sea surface, based on merged HR-XBT/Argo/altimetry using trajectory-based reference velocities at $1000 \mathrm{~m}$ (merged-data absolute velocity) and averaged from 2004 to 2015, are presented in Fig. 7a. West of $155.2^{\circ} \mathrm{E}$, results show southward velocities between $1200 \mathrm{~m}$ and the sea surface indicative of the EAC. Below 1600-m depth, the flow near the continental shelf changes sign and becomes northward. The slow-moving northward flow $\left(<0.025 \mathrm{~m} \mathrm{~s}^{-1}\right)$ underneath the EAC is consistent with the signature of the EAC undercurrent (Mata et al. 2000). No evident EAC undercurrent signature is observed when using a reference level at $1975 \mathrm{~m}$ (Fig. 7b). East of $155.2^{\circ} \mathrm{E}$, velocities in the reference-level calculation show northward values indicative of the EAC recirculation that extend deeper than trajectory-based estimates (Figs. 7a,b). The discrepancies between the trajectory-based absolute velocity and reference-level estimates arise from trajectory velocities at $1000 \mathrm{~m}$ (Fig. 7c, black line) that are smaller than in the reference-level calculation (Fig. 7c, blue line) in the EAC and oriented in opposite direction to reference-level estimates in the EAC recirculation region. Absolute velocities derived from Argo-only data, including trajectory-based reference velocities at $1000 \mathrm{~m}$, averaged between 2004 and 2015, are shown in Fig. 7d. Absolute velocities in the EAC and recirculation based on the Argo-only dataset are consistent with estimates based on merged data, though smoother. Similarities between the velocity estimates in Figs. 7a and 7d include the vertical extents of the EAC and recirculation to $1200 \mathrm{~m}$, the northward flow characteristic of the EAC undercurrent underneath the EAC, and the southward flow observed below the EAC recirculation.

Time-mean estimates of absolute geostrophic transport, integrated between 1975-m depth and the sea surface, and accumulated eastward are presented in Fig. 8. Merged-data results (blue line with light-blue error bars) show the offshore limit of the EAC at $155.2^{\circ} \mathrm{E}, 40 \mathrm{~km}$ inshore compared to Argo-only data. Transport estimates from merged data are $19.5 \pm 2.0 \mathrm{~Sv}$ southward in the EAC and $2.5 \pm 0.5 \mathrm{~Sv}$ northward in the EAC recirculation region, and the net transport

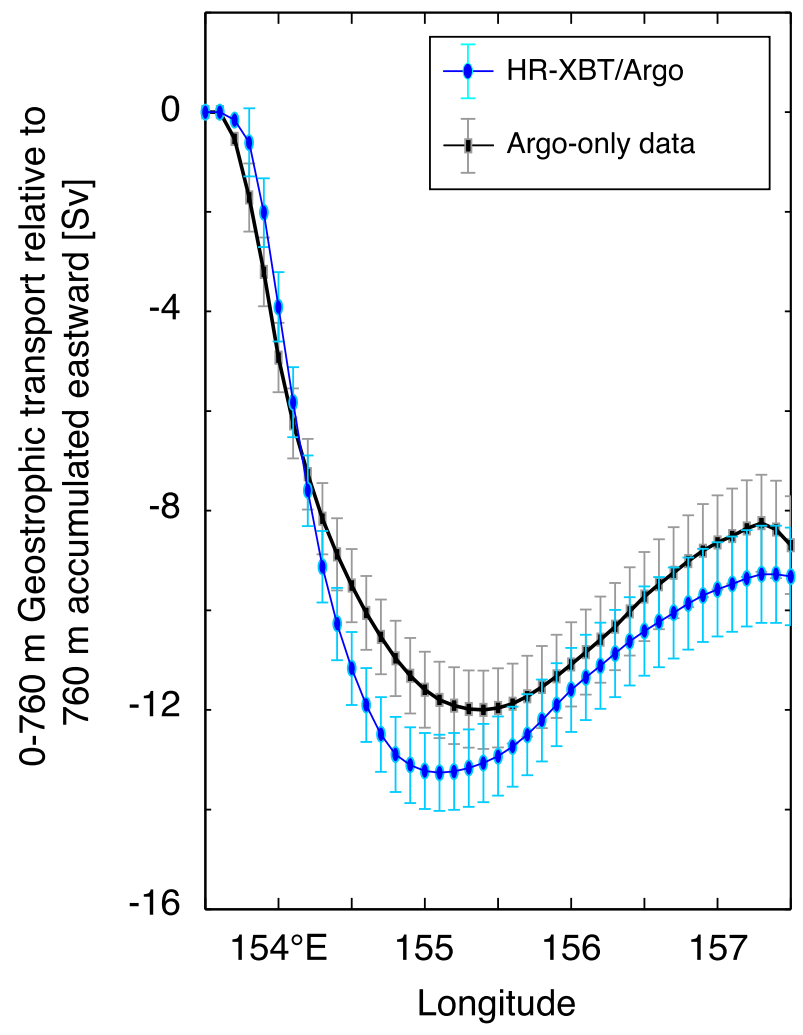

FIG. 6. Geostrophic transport relative to $760 \mathrm{~m}$ normal to the PX30 nominal track, integrated for 0-760 m, cumulatively summed eastward based on HR-XBT/Argo (blue) and Argo-only data (black), averaged between 2004 and 2015. Light-blue and gray error bars show random error associated with the trajectory density in Argo data (see text).

west of $157.5^{\circ} \mathrm{E}$ is $17.0 \pm 2.5 \mathrm{~Sv}$. The transport in the EAC is consistent with moored observations from the PCM3 moored array at $30^{\circ} \mathrm{S}$ by Mata et al. (2000). The Argo-only computation (black line with gray error bars) shows transport values of $17.6 \pm 2.0 \mathrm{~Sv}$ southward in the EAC west of $155.4^{\circ} \mathrm{E}$, and $1.4 \pm 0.5 \mathrm{~Sv}$ northward in the EAC recirculation region between $155.4^{\circ}$ and $157.5^{\circ} \mathrm{E}$, which is smaller than estimated using merged data.

\section{b. Velocity estimates averaged between April 2012 and August 2013}

An array of six moorings near $27^{\circ} \mathrm{S}$, nearly parallel to the PX30 transect but offset about $68 \mathrm{~km}$ to the south (Fig. 1), was deployed by CSIRO in April 2012 and recovered in August 2013 (Sloyan et al. 2016). The array extended from the continental shelf out to abyssal waters near $155.3^{\circ} \mathrm{E}$. Following an 18 -month hiatus, the array was redeployed in May 2015. Only the initial deployment was available for the present analysis, but a longer-term comparison will be possible in the future. 

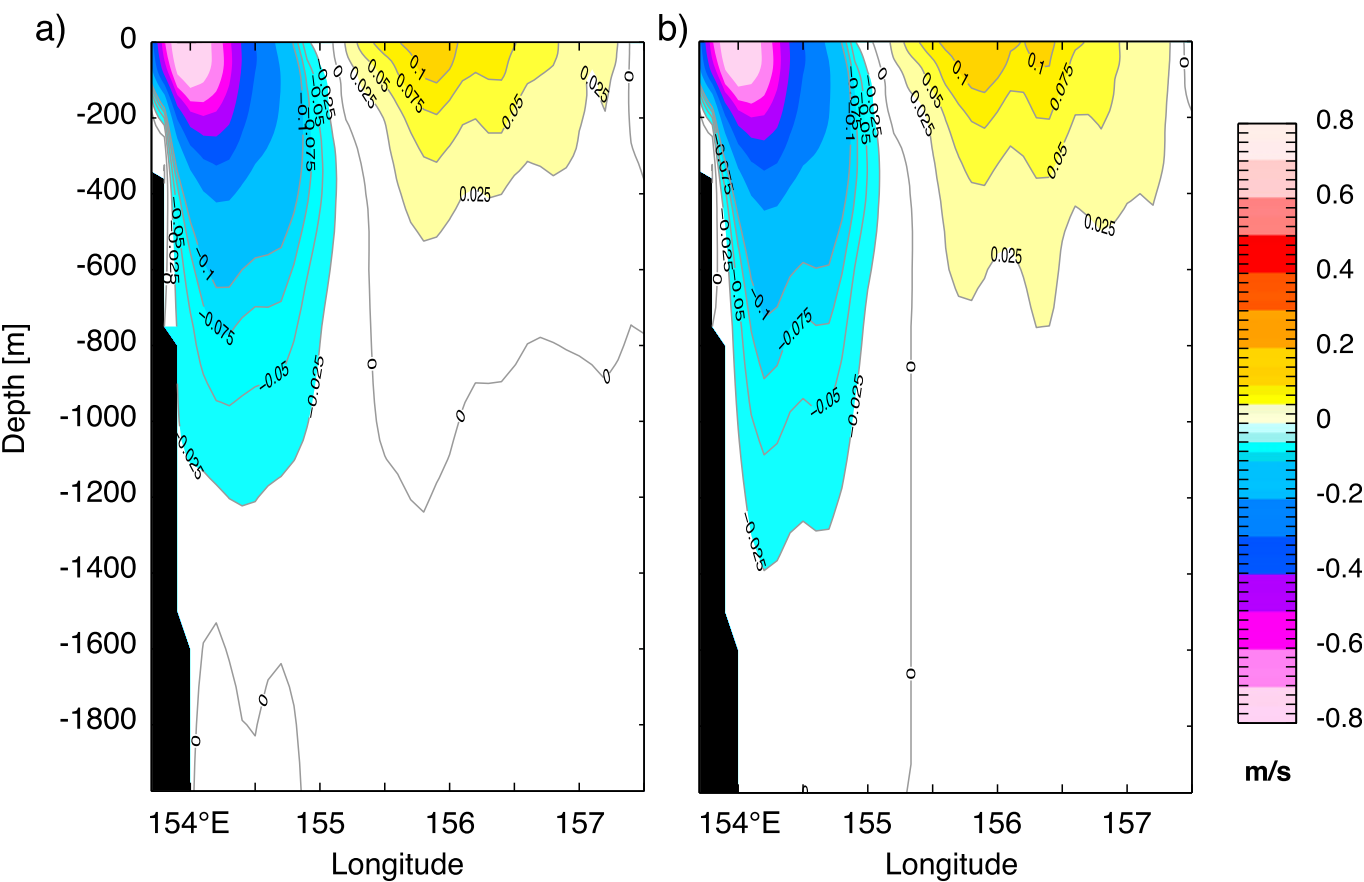

c)

d)
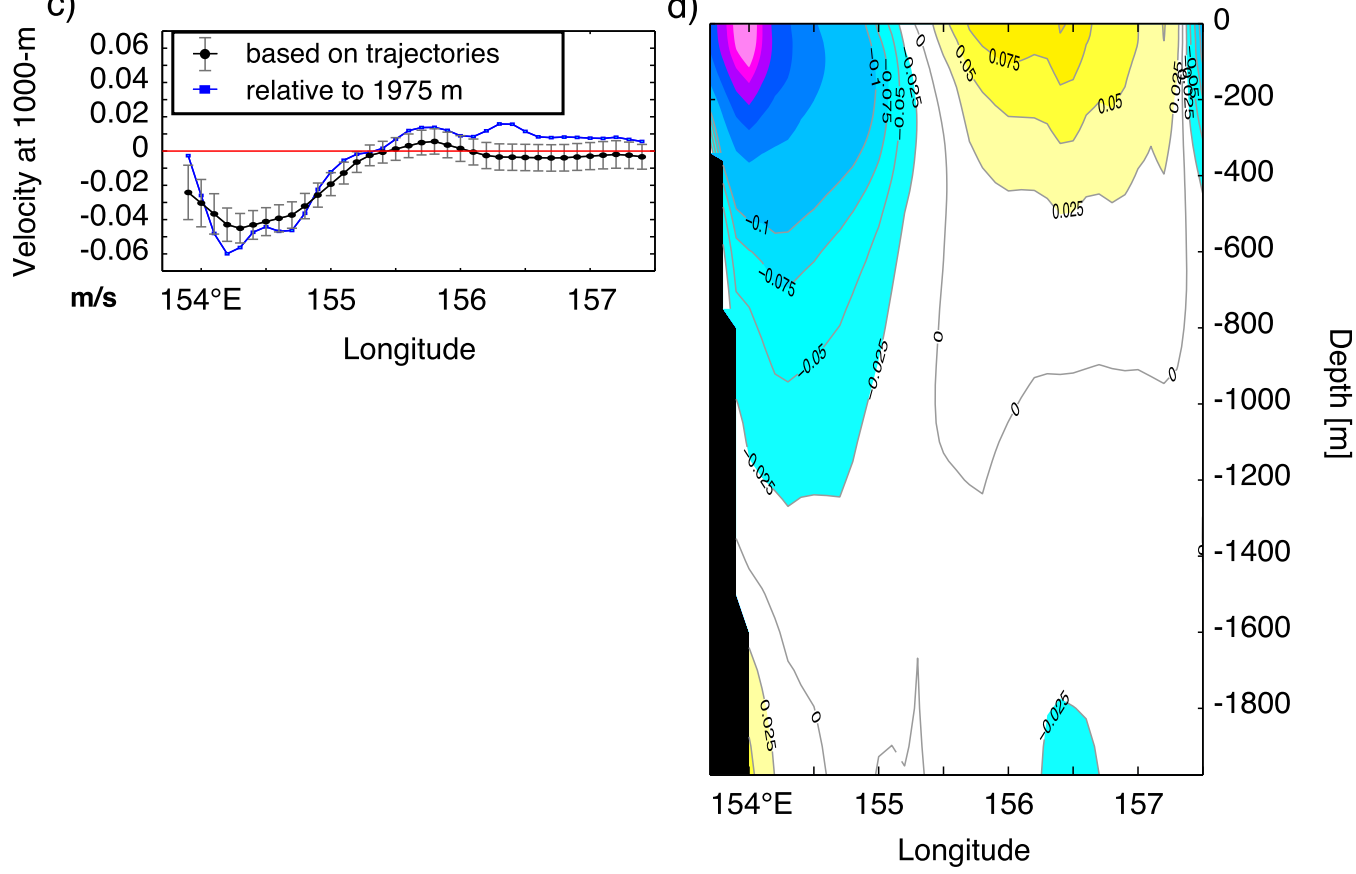

FIG. 7. Geostrophic velocity normal to the PX30 nominal track between $1975 \mathrm{~m}$ and the sea surface along PX30 nominal transect averaged between 2004 and 2015. Contour intervals are $0.1 \mathrm{~m} \mathrm{~s}^{-1}$ for velocities greater than $0.1 \mathrm{~m} \mathrm{~s}^{-1}$ and less than $-0.1 \mathrm{~m} \mathrm{~s}^{-1}$, and $0.025 \mathrm{~m} \mathrm{~s}^{-1}$ for velocities from -0.1 to $0.1 \mathrm{~m} \mathrm{~s}^{-1}$. The zero velocity contour is indicated. (a) Absolute velocity based on merged data. (b) Merged-data relative velocity using a reference level at 1975 m. (c) Geostrophic velocity at 1000-m depth along PX30 nominal transect averaged between 2004 and 2015. Absolute velocity is estimated using trajectory-based velocities (black). Relative velocity is calculated with a reference level at $1975 \mathrm{~m}$ (dark blue). (d) Absolute velocity estimated using Argo-only data. 
Figure 9 compares absolute velocity estimates computed using merged data at PX30 with velocity observations from the mooring array. During this period, the mergeddata absolute velocity values in the EAC and EAC undercurrent, averaged during the mooring deployment, were similar to the 2004-15 mean estimates (Figs. 9a, 7a). East of the EAC, northward velocities indicative of the EAC recirculation gyre change directions between $156.7^{\circ}$ and $157.5^{\circ} \mathrm{E}$ (Fig. 9a). The meandering of the EAC recirculation is likely due to interaction with the topography as the flow approaches the Dampier Ridge east of our study area (Van der Linden 1970; Tilburg et al. 2001). Velocity estimates computed at the mooring array (data courtesy of Bernadette Sloyan), rotated perpendicular to the PX30 nominal transect and averaged during the mooring time period, are presented in Fig. 9b. The structure of the EAC and undercurrent from the moored observations are very similar to merged-data estimates at the PX30 transect (Figs. 9a,b). Small differences between the two products include velocity values from moored data being $0.1-0.2 \mathrm{~m} \mathrm{~s}^{-1}$ smaller than at PX30 at the core of the EAC and $0.025 \mathrm{~m} \mathrm{~s}^{-1}$ higher below $200 \mathrm{~m}$ in the EAC recirculation. This could be due to the limited spatial sampling by the moored array, and the spatial variability of the EAC and EAC recirculation between the PX30 nominal transect and the mooring array. Sloyan et al's (2016) moorings were separated by $11 \mathrm{~km}$ west of $154^{\circ} \mathrm{E}$, by $30-35 \mathrm{~km}$ from $154^{\circ}$ to $154.6^{\circ} \mathrm{E}$, and by $65 \mathrm{~km}$ for the two moorings farthest offshore (Fig. 9b). The spatial sampling of HR-XBT profiles along PX30 (8-10 km west of $155^{\circ} \mathrm{E}$ and $25-35 \mathrm{~km}$ between $155^{\circ}$ and $157.5^{\circ} \mathrm{E}$ ) is denser than that of the moored array. The overall good agreement between upper-1975-m time-mean EAC velocities from these two methods (merged data, with higher spatial resolution; and moorings, with higher temporal resolution and top-to-bottom observations) demonstrates the robustness of our method to estimate the time-mean EAC velocity and transport.

\section{c. Time variability of the volume transport between 2004 and 2015}

\section{1) Transport in the EAC}

Monthly means of volume transport at PX30, integrated in the upper $1975 \mathrm{~m}$ between $153.5^{\circ}$ and $155.3^{\circ} \mathrm{E}$, the offshore edge of the mooring array from Sloyan et al. (2016), are estimated from the merged-data absolute velocities. Transport estimates are smoothed using a 4-month running mean (black line with square symbols) as shown in Fig. 10. On this time scale, the highest values of the southward transport $(<-25 \mathrm{~Sv})$ were in 2004, 2009, and 2010, and the lowest values $(>-15 \mathrm{~Sv})$ were in 2008 and at the end of

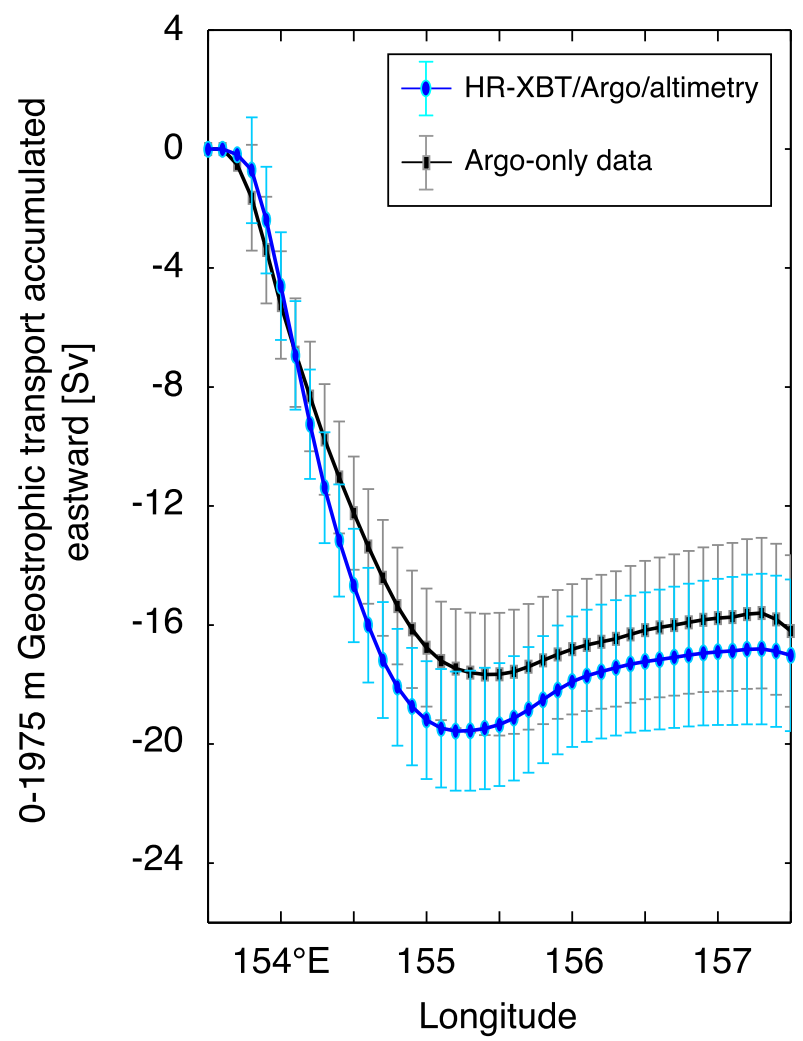

FIG. 8. Absolute geostrophic transport normal to the PX30 nominal track integrated for $0-1975 \mathrm{~m}$ cumulatively summed eastward based on merged data (blue) and Argo-only data (black), in both cases combined with trajectory-based velocity at parking depth. Light-blue and gray error bars show random error associated with the time-varying trajectory density in Argo data.

2013. Monthly estimates of the transport derived using moored data at $27^{\circ} \mathrm{S}$, integrated in the upper $1975 \mathrm{~m}$ between $153.5^{\circ}$ and $155.3^{\circ} \mathrm{E}$, and again smoothed using a 4-month running mean (solid red line with round symbols), are shown for comparison. The 18-month averaged transport is 21.1 Sv at the moored array and 23.3 Sv from PX30. The transport mean difference of $2.2 \mathrm{~Sv}$ between the two estimates represents the upper bound of the transport uncertainty in the HR-XBT/Argo/altimetry method; that is, the difference also includes any spatial difference between the two lines $68 \mathrm{~km}$ apart, and errors or spatial undersampling in the moored array transport estimates. Results from the merged data (black line with square symbols) indicate a 5-Sv transport decrease of the transport from September 2012 to January 2013, and a 4-Sv increase from January to May 2013, consistent with the moored observations. Although the mooring deployment period is limited, the agreement between changes in transport at PX30 and the moored array supports the robustness of our method to estimate the time variability of the transport in the EAC at interannual and longer time scales. 

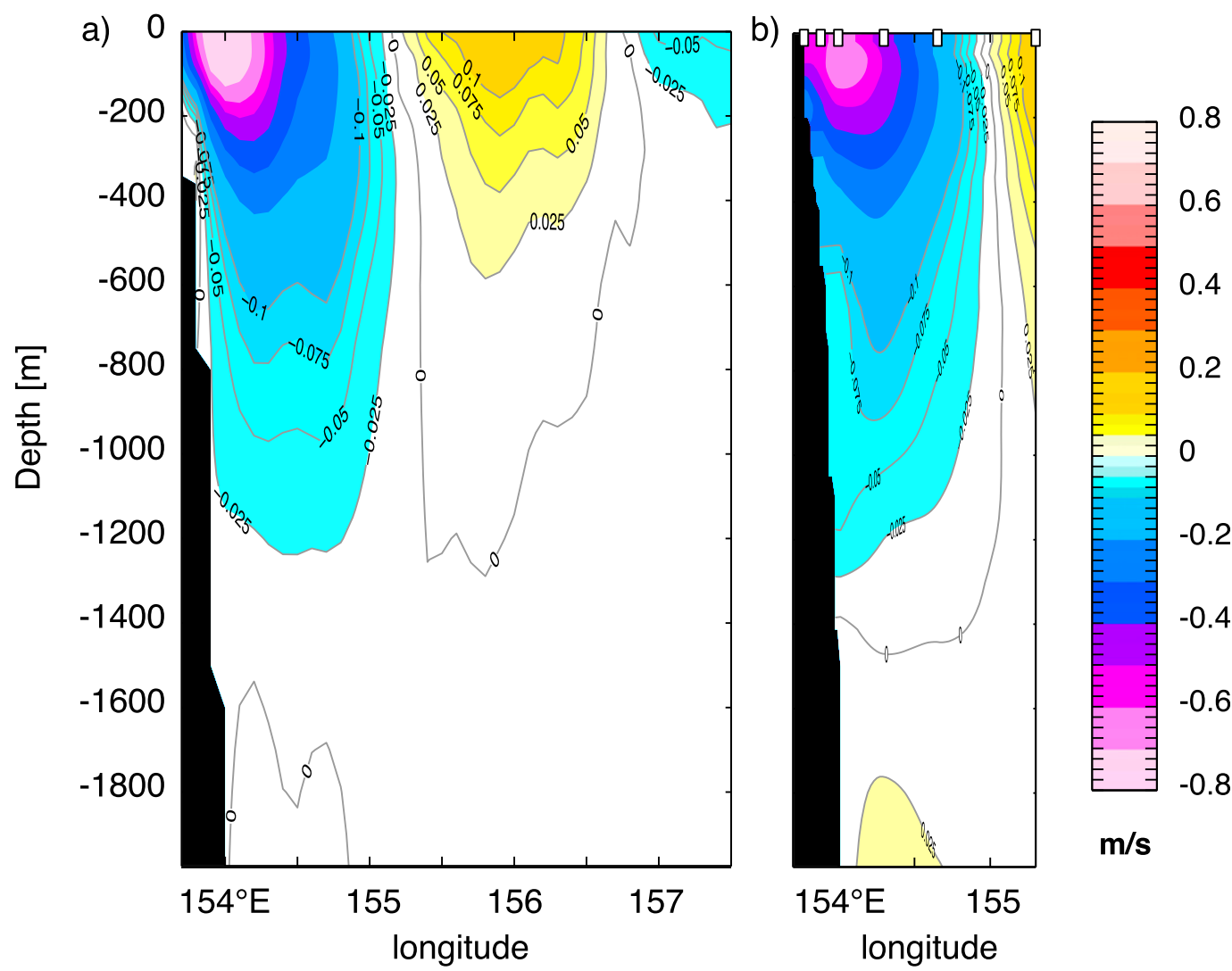

FIG. 9. Absolute geostrophic velocity normal to the PX30 nominal track between $1975 \mathrm{~m}$ and the sea surface, computed using (a) using merged data at PX30 and (b) moored data at $27^{\circ} \mathrm{S}$, averaged over the mooring deployment period. The locations of moorings used for analysis in Sloyan et al. (2016) are indicated as white marks at the top of Fig. 9b. Contour intervals are $0.1 \mathrm{~m} \mathrm{~s}^{-1}$ for velocities higher than $0.1 \mathrm{~m} \mathrm{~s}^{-1}$ and lower than $-0.1 \mathrm{~m} \mathrm{~s}^{-1}$, and $0.025 \mathrm{~m} \mathrm{~s}^{-1}$ for velocities from -0.1 to $0.1 \mathrm{~m} \mathrm{~s}^{-1}$.

The annual cycle of the EAC transport at PX30 is inferred using unsmoothed monthly transport estimates from merged data, integrated in the upper $1975 \mathrm{~m}$ between $153.5^{\circ}$ and $155.3^{\circ} \mathrm{E}$. The $2004-15$ monthly means of the transport are shown in Fig. 11. The EAC shows a weakly significant seasonal cycle with transport values stronger in summer compared with winter, consistent with Ridgway and Godfrey (1997). Maximum transport $(21.6 \pm 1.4 \mathrm{~Sv})$ occurs in March and minimum transport $(18 \pm 1.4 \mathrm{~Sv})$ in August, in agreement with observations by Wood et al. (2016). Unsmoothed monthly estimates of the EAC transport at PX30 are consistent with moored data at $27^{\circ} \mathrm{S}$ (not shown).

\section{2) TRANSPORT IN THE EAC SYSTEM, INCLUDING RECIRCULATION}

A time series of the transport in the EAC system is estimated by integrating transport from the onshore end of PX30 to the offshore edge of the EAC recirculation. Since the recirculation cells are localized along coast, the net transport of the southward EAC and the northward recirculation may be a better indicator of the WBC transport and variability than the southwardflowing EAC alone. The time-varying offshore limit of the EAC recirculation (Fig. 12, solid red line with square symbols) is estimated from the position of flow reversal between the northward EAC recirculation and the weak southward flow farther to the east. Displacements of up to $140 \mathrm{~km}$ are seen in the EAC recirculation offshore edge at interannual time scale (Fig. 12). Alternatively, a constant offshore edge of the recirculation at $157.5^{\circ} \mathrm{E}$ (solid black line in Fig. 12), is chosen based on the 2004-15 mean velocity estimates [section 3a(2); Fig. 7a].

For the two choices of the offshore edge of the EAC system (time-varying and constant longitude), geostrophic transport anomalies relative to the 2004-15 mean, smoothed using a 1-yr running mean, are presented in Fig. 13. The interannual variability of the transport is characterized by moderate $(>2 \mathrm{~Sv}$ ) positive anomalies relative to the 2004-15 mean estimate of the volume 


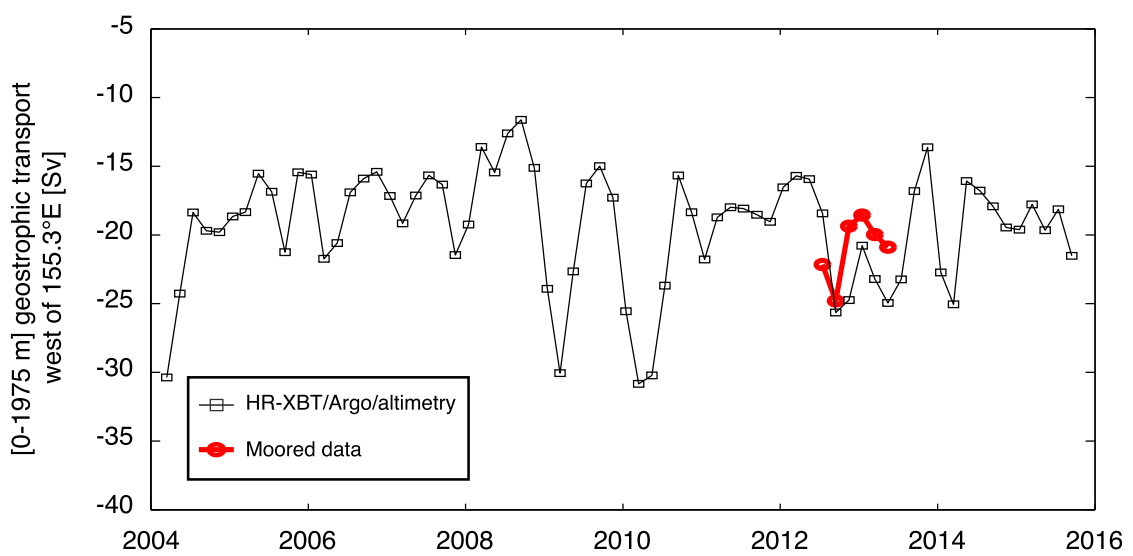

FIG. 10. Time series of the absolute geostrophic transport normal to the PX30 nominal track in the EAC region west of $155.3^{\circ} \mathrm{E}$ from 2004 to 2015 , computed using merged data (black line). Transport estimates using moored data at $27^{\circ} \mathrm{S}$ (red line). Both series are smoothed with a 4-month running mean.

transport, between 2004 and 2009. During 2010-15, the transport anomalies appear to exhibit a 2- to 3-yr periodicity with the largest $(<-4 \mathrm{~Sv})$ negative values, indicative of the strongest southward transport of the EAC, in 2010 and 2013, and moderate positive values in 2012 and 2014. The standard deviation of the interannual anomalies of the geostrophic transport is 3.1 Sv between 2004 and 2015. Observed changes in the offshore edge of the EAC recirculation (Fig. 12) do not strongly affect the transport estimates (Fig. 13).

\section{Summary and conclusions}

The method developed in this work improves longterm estimates of the volume transport in WBCs regions sampled by the HR-XBT network. This method is based on temperature transects from the HR-XBT network in the upper $760 \mathrm{~m}$, Argo temperature and salinity data between $1975 \mathrm{~m}$ and the sea surface, Argo trajectories at 1000-m depth, and altimetric SSH data. Velocity and transport estimates are presented for the case of the EAC near Brisbane. This region was chosen to test the capabilities of our method because of the availability of HR-XBT transects, relatively good coverage of Argo profile and trajectory data, and nearby independent reference data from moored arrays. For this study results are presented over a 12-yr period from 2004 to 2015, and the method can be updated when the continuing HR-XBT, Argo, and altimetric datasets are available.

According to an analysis of Argo-based observations by Zilberman et al. (2014), about $25 \%$ of the upper 2000-m equatorward transport in the interior South Pacific at $32^{\circ} \mathrm{S}$ returns southward in the EAC system. The net northward upper-ocean geostrophic transport in the South Pacific provides most of the volume transport feeding the Indonesian Throughflow (Zilberman et al. 2013, 2014). While the mean transports into and out of the Pacific balance reasonably well, and in spite of neglecting the deep ocean components, a challenge for the observing system is to estimate the basin-scale transports in the time-varying interannual sense. In other words, can the EAC system, the interior transport of the South Pacific Gyre, the storage of upper-ocean waters through vertical advection, and the Indo-Pacific exchange through Indonesian seas all be observed accurately enough to close interannual mass and heat budgets? The present work is a step in that direction.

Despite drawing a large interest within the scientific community, the seasonal to decadal variability of the

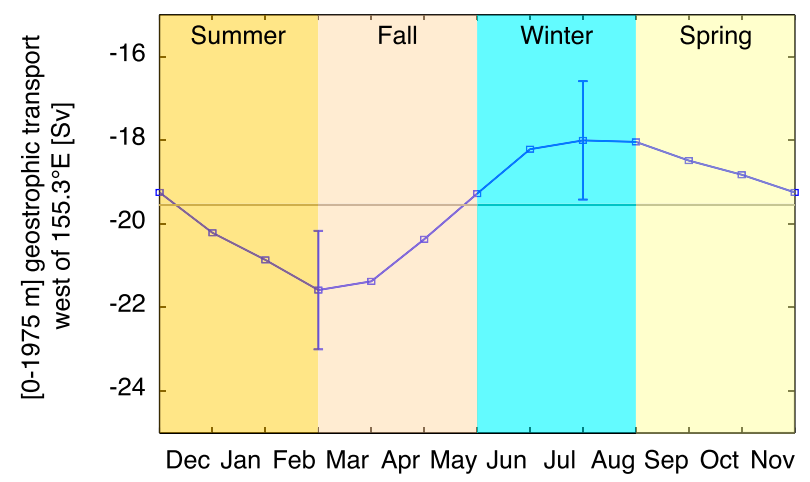

FIG. 11. Annual cycle of the absolute geostrophic transport normal to the PX30 nominal track in the EAC region west of $155.3^{\circ} \mathrm{E}$ from 2004 to 2015 , computed using merged data. The 2004 15 mean transport estimate (gray line) is indicated. The standard error of the monthly estimates relative to seasonal means is represented. 


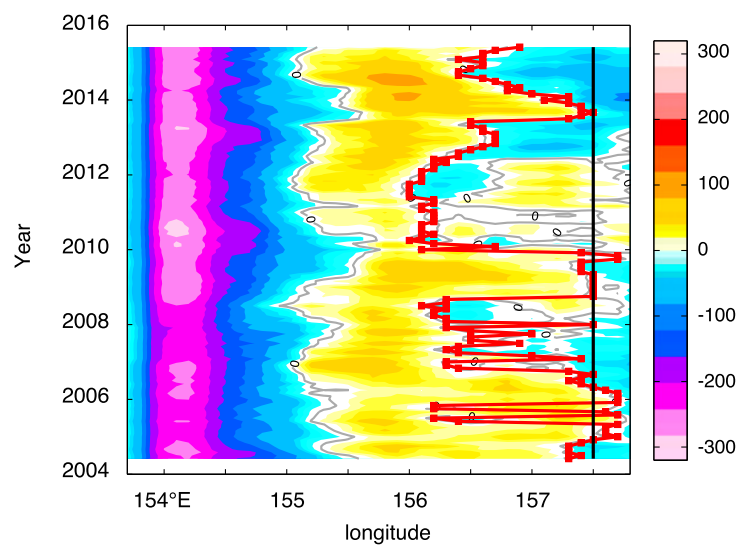

FIG. 12. Depth-integrated absolute velocity normal to the PX30 nominal track in the EAC and recirculation estimated using merged data between 2004 and 2015. The zero-depth-integrated velocity contour (gray line). The time-varying offshore edge of the EAC recirculation (solid red line with square red symbols). The offshore edge of the EAC recirculation at $157.5^{\circ} \mathrm{E}$, inferred from the transport accumulated eastward averaged between 2004 and 2015 (solid black line).

EAC transport, including its linkage to El NiñoSouthern Oscillation and the southern annular mode, as well as to variations in the Indonesian Throughflow, is not well understood (Ridgway et al. 2008; Hill et al. 2011). The presented method provides long-term times series of the EAC near Brisbane and can be applied to other HR-XBT transects spanning the EAC system. By extending the temporal domain of moored observations to decadal and longer time scales, the relationship of WBC transport to forcing functions and climate indices can be discovered. Similarly, the extension of the spatial domain of moored observations to include the recirculation region produces estimates of net WBC transport that are more consistent with interior forcing and other basin-scale variability than is the case with the WBC alone. A feasible approach moving forward is to study the along-current variability of the transports of heat and freshwater in the EAC. In future work we plan to apply this method to the EAC extension and the East Auckland Current (EAuC), and to make a comparison with the observations near Brisbane. A "whole Pacific" approach, including the low-latitude and North Pacific circulations, is also envisaged.

Transport estimates for the mean EAC system near Brisbane based on merged data show velocity values at the core of the EAC and recirculation that are marginally higher than the Argo-only estimates of the 2004-15 mean (Figs. 7a,d), and with a sharper EAC signature. Comparisons between merged data along PX30 and moored observations at $27^{\circ} \mathrm{S}$ show agreement within $2.2 \mathrm{~Sv}$ for 2012-13 mean estimates of the EAC transport,

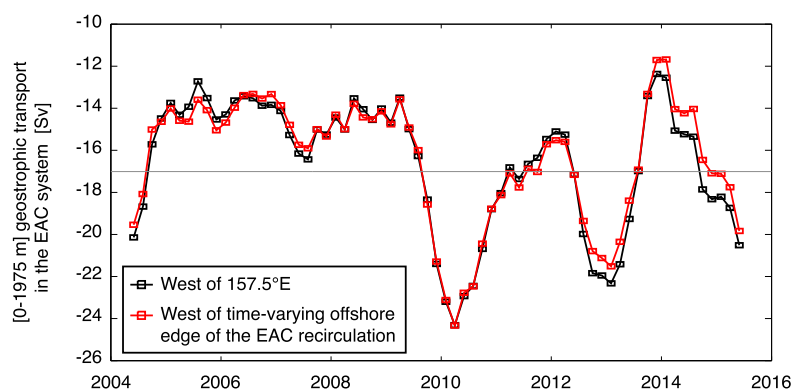

FIG. 13. Time series of the absolute geostrophic transport normal to the PX30 nominal track in the EAC system, including EAC and recirculation, from 2004 to 2015, estimated using merged data. Estimates of the transport west of $157.5^{\circ} \mathrm{E}$, offshore edge of the EAC system estimated from 2004 to 2015 mean transport (black line). Estimates using time-varying offshore edge of the EAC transport (red line). The 2004-15 mean value of the transport west of $157.5^{\circ} \mathrm{E}$ (thin gray line).

and consistency between 4-month anomalies (Fig. 10). The good agreement seen between the mean and lowfrequency variability of the geostrophic transport across PX30, and the overlapping observations from the nearly collocated mooring array provides evidence of the robustness of our method.

Sustained observation of the ocean's boundary currents is an important missing element of the sustained global ocean observing system. Recommendations from the OceanObs'09 Conference include deployments of moored arrays at key locations, synergies between observational techniques, and application of new technologies, such as autonomous underwater gliders (Send et al. 2010). Sustaining topto-bottom moored arrays for multiyear periods to capture the low-frequency variability in boundary current transport is a challenging task. Combining HR-XBT, satellite altimetry, and Argo datasets with moored observations and shipboard data has been shown to be an effective means of leveraging limitedduration records into longer-term estimates (Imawaki et al. 2001; Ridgway et al. 2008; van Sebille et al. 2010). Here, results based on HR-XBT transects combined with Argo and altimetry complement moored observations. Velocity estimates along PX30 have longer time series, higher spatial resolution, and farther offshore extension than those from the moored array at $27^{\circ} \mathrm{S}$. The mooring data, on the other hand, have a sampling frequency that is much higher than the quarterly HR-XBT transects, and they provide the highest-quality reference values of EAC velocities from the ocean bottom to the sea surface.

The method developed here is distinguished from earlier studies through its use of datasets from observing programs that regularly sample all the midlatitude WBCs 
of the World Ocean. This case study will be expanded to the East Auckland Current, the Kuroshio, the Gulf Stream, the Brazil Current, and the Agulhas Current. Our long-term goal is to define a new set of ocean climate indicators to track the interannual variability in WBC transport in the subtropical gyres. This will allow us to quantify WBC components of the heat and freshwater budgets and transport in the oceanic MOCs. The maintenance of the HR-XBT network, Argo array, and satellite altimetry will make it possible.

Acknowledgments. The authors thank Lisa Lehmann, Megan Scanderbeg, and Janet Sprintall for their valuable suggestions; Bernadette Sloyan for providing the mooring data; and CSIRO for collecting the HR-XBT observations along the PX30 transects. NZ was supported by SIO CIMEC Argo and CORC (NOAA Grant NA15OAR4320071), NOAA (Grant NA14OAR4310219), and NASA (Grant NNX13AE82G). Participation by SG was supported by NSF (Grant PLR-1425989) and NASA (Grant NNX13AE44G). The Argo data used here (http://doi.org/10.17882/42182) were collected and made freely available by the international Argo program and by the national programs that contribute to it. The HR-XBT data were made available by the Scripps high resolution XBT program (www-hrx.ucsd. edu). The altimeter products were produced and distributed by Aviso (http://www.aviso.altimetry.fr/), as part of the SSALTO ground processing segment.

\section{APPENDIX}

\section{Salinity Estimate from HR-XBT Temperature}

Each HR-XBT temperature is paired with an estimate of salinity through a two-step procedure. The initial step results in a climatological estimate similar to using a standard temperature-salinity (TS) relation but with the benefit of defaulting to a depth-salinity relation in those areas without a strong TS correlation. The climatological estimate is robust because of the large quantity of Argo data accumulated over the 12 -yr period. The second step estimates the time variability of TS. In the present calculation, the difference is negligible $(\sim 0.1 \mathrm{~Sv})$ between geostrophic transport estimates based on climatological and time-varying TS. For completeness, both steps are described.

A simple linear regression model $\beta$ between temperature $(T)$ and salinity $(S)$ is calculated using spatially close (within $3^{\circ}$ ) Argo float data,

$$
S_{\mathrm{XBT}}=S_{\mathrm{RG}}+\beta \times\left(T_{\mathrm{XBT}}-T_{\mathrm{RG}}\right),
$$

where $\beta=\sum\left(T_{A}-T_{\mathrm{RG}}\right) \times\left(S_{A}-S_{\mathrm{RG}}\right) / \sum\left(T_{A}-T_{\mathrm{RG}}\right)^{2}$ and subscript $A$ indicates Argo data, subscript RG indicates a first estimate based on spatial position and annual month (e.g., January) within the Argo climatology from Roemmich and Gilson (2009), and subscript XBT indicates HR-XBT temperature.

In those regions and depths with strong TS correlations, the model improves the depth-salinity first estimate (RG) toward a TS-determined estimate. However, where the correlation is weak (model coefficient is zero) the depth-salinity estimate is retained. The model boxcar averaging scale is similar to the Argo program array float spacing and results in a smooth transition between TS and depth-salinity estimates. The computed linear correlation model has an overall strong TS signature in the PX30 region (not shown). The correlation is weak only at inflection points of the TS relation at temperatures near 200-m depth. Not all HR-XBT repeat hydrography lines have such a consistently strong TS signature, so a general method that can handle both is beneficial.

In the second step, contemporaneous salinity measurements improve the salinity estimate of those HR-XBT cruises within the Argo program era or with expendable conductivity temperature depth (XCTD) deployments. At each depth level, the "nearest" subset of 100 data salinity anomalies relative to the RG climatology are objectively mapped to the location of the HR-XBT [Bretherton et al. 1976, their Eq. (20)]. The contemporary data undergo some quality control, closely following the procedure described by Roemmich and Gilson (2009), and they are subsampled every $5 \mathrm{~m}$ to reduce the weight of finely sampled (with pressure/depth) reference profiles.

Three metrics of distance are weighted equally to identify the most relevant nearby data. First, spatial distance as measured by latitudinal and longitudinal degrees ( $e$-folding scale of $2.0^{\circ}$ ) is combined with temporal displacement (e-folding of 3.5 days). Second, a climatological SH difference is calculated from the RG climatology between the location of the HR-XBT and reference data ( $e$-folding scale of 2 dyn- $\mathrm{cm}$ ), which is designed to penalize reference data that are in spatial proximity but are estimated to be across strong geostrophic currents. Third, the climatological TS correlation computed in step 1 is used to identify the linear weight of a distance penalty based on temperature versus one based on depth. Higher correlations such as computed across the HR-XBT PX30 thermocline are primarily penalized by temperature. The $e$-folding scale of depth varies linearly from $10 \mathrm{~m}$ near the surface to $60 \mathrm{~m}$ at $800 \mathrm{~m}$. The temperature $e$-folding scale is based on the RG climatological range between $800-\mathrm{m}$ depth and the sea 
surface. Similar to the depth $e$-folding scale, the temperature $e$-folding is smaller near the surface than at $800 \mathrm{~m}$.

The final salinity estimate sums the above described climatological first guess and an objectively mapped correction toward measured salinity from other contemporaneous data sources. The same procedure is applied to all HR-XBT transects to be consistent whether independent salinity measurements are available. The salinity within the well-mixed surface layer (HR-XBT temperature within $0.1^{\circ} \mathrm{C}$ of the surface value) is assumed to be constant and is assigned the averaged value of the estimated salinity values over that depth range.

\section{REFERENCES}

Archer, M. R., M. Roughan, S. R. Keating, and A. Schaeffer, 2017: On the variability of the East Australian Current: Jet structure, meandering, and influence on shelf circulation. J. Geophys. Res. Oceans, 122, 8464-8481, https://doi.org/ 10.1002/2017JC013097.

Beal, L. M., and S. Elipot, 2016: Broadening not strengthening of the Agulhas Current since the early 1990s. Nature, 540, 570573, https://doi.org/10.1038/nature19853.

— , T. K. Chereskin, Y. D. Lenn, and S. Elipot, 2006: The sources and mixing characteristics of the Agulhas Current. J. Phys. Oceanogr., 36, 2060-2074, https://doi.org/10.1175/JPO2964.1.

Bretherton, F., R. Davis, and C. Fandry, 1976: A technique for objective analysis and design of oceanographic experiments applied to MODE-73. Deep-Sea Res. Oceanogr. Abstr., 23, 559-582, https://doi.org/10.1016/0011-7471(76)90001-2.

Cai, W., and Coauthors, 2012: More extreme swings of the South Pacific convergence zone due to greenhouse warming. Nature, 488, 365-369, https://doi.org/10.1038/nature11358.

Cheng, L., and Coauthors, 2016: XBT science: Assessment of instrumental biases and errors. Bull. Amer. Meteor. Soc., 97, 924-933, https://doi.org/10.1175/BAMS-D-15-00031.1.

Cowley, R., S. Wijffels, L. Cheng, T. Boyer, and S. Kizu, 2013: Biases in expendable bathythermograph data: A new view based on historical side-by-side comparisons. J. Atmos. Oceanic Technol., 30, 1195-1225, https://doi.org/10.1175/JTECHD-12-00127.1.

Gille, S. T., 2003: Float observations of the Southern Ocean. Part I: Estimating mean fields, bottom velocities, and topographic steering. J. Phys. Oceanogr., 33, 1167-1181, https://doi.org/ 10.1175/1520-0485(2003)033<1167:FOOTSO > 2.0.CO;2.

Goni, G., and Coauthors, 2010: The Ship of Opportunity Program. Proceedings of OceanObs'09: Sustained Ocean Observations and Information for Society, J. Hall, D. E. Harrison, and D. Stammer, Eds., Vol. 2, ESA Publ. WPP-306, https://doi.org/ 10.5270/OceanObs09.cwp.35.

Gray, A. R., and S. C. Riser, 2014: A global analysis of Sverdrup balance using absolute geostrophic velocities from Argo. J. Phys. Oceanogr., 44, 1213-1229, https://doi.org/10.1175/ JPO-D-12-0206.1.

Hanawa, K., P. Rual, R. Bailey, A. Sy, and M. Szabados, 1995: A new depth-time equation for Sippican or TSK T-7, T-6 and $T$-4 expendable bathythermographs (XBT). Deep-Sea Res. I, 42,1423-1451, https://doi.org/10.1016/0967-0637(95) 97154-Z.
Hill, K., S. R. Rintoul, K. R. Ridgway, and P. R. Oke, 2011: Decadal changes in the South Pacific western boundary current system revealed in observations and ocean state estimates. J. Geophys. Res., 116, C01009, https://doi.org/10.1029/ 2009JC005926.

Hu, D., and Coauthors, 2015: Pacific western boundary currents and their roles in climate. Natl. Rev., 522, 299-308, https:// doi.org/10.1038/nature14504.

Huang, R. X., 2010: Ocean Circulation: Wind-Driven and Thermohaline Processes. Cambridge University Press, 791 pp.

Imawaki, S., H. Uchida, H. Ichikawa, M. Fukasawa, and S. Umatani, and the ASUKA Group, 2001: Satellite altimeter monitoring the Kuroshio transport south of Japan. Geophys. Res. Lett., 28, 17-20, https://doi.org/10.1029/2000GL011796.

Kang, D., and E. N. Curchitser, 2013: Gulf Stream eddy characteristics in a high-resolution ocean model. J. Geophys. Res. Oceans, 118, 4474-4487, https://doi.org/10.1002/ jgrc. 20318.

Kwon, Y., M. A. Alexander, N. A. Bond, C. Frankignoul, H. Nakamura, B. Qiu, and L. A. Thompson, 2010: Role of the Gulf Stream and Kuroshio-Oyashio systems in a large-scale atmosphere-ocean interaction: A review. J. Climate, 23, 32493281, https://doi.org/10.1175/2010JCLI3343.1.

Levitus, S., J. I. Antonov, T. P. Boyer, R. A. Locarnini, H. E. Garcia, and A. V. Mishonov, 2009: Global ocean heat content 1955-2008 in light of recently revealed instrumentation problems. Geophys. Res. Lett., 36, L07608, https://doi.org/10.1029/ 2008GL037155.

Lien, R.-C., and Coauthors, 2015: The Kuroshio and Luzon Undercurrent east of Luzon Island. Oceanography, 28 (4), 54-63, https://doi.org/10.5670/oceanog.2015.81.

Mata, M. M., M. Tomczak, S. Wijffels, and J. A. Church, 2000: East Australian Current volume transports at $30^{\circ} \mathrm{S}$ : Estimates from the World Ocean Circulation Experiment hydrographic sections PR11/P6 and the PCM3 current meter array. J. Geophys. Res., 105, 28 509-28 526, https://doi.org/10.1029/ 1999JC000121.

Meinen, C. S., and D. S. Luther, 2016: Structure, transport, and vertical coherence of the Gulf Stream from the Straits of Florida to the Southeast Newfoundland Ridge. Deep-Sea Res. I, 112, 137-154, https://doi.org/10.1016/j.dsr.2016.03.002.

Ollitrault, M., and J. P. Rannou, 2013: ANDRO: An Argo-based deep displacement dataset. J. Atmos. Oceanic Technol., 30, 759-788, https://doi.org/10.1175/JTECH-D-12-00073.1.

Ridgway, K. R., and J. S. Godfrey, 1997: Seasonal cycle of the East Australian Current. J. Geophys. Res., 102, 22 921-22 936, https://doi.org/10.1029/97JC00227.

— Australian Current System and its relationship with topography. Prog. Oceanogr., 56, 189-222, https://doi.org/10.1016/ S0079-6611(03)00004-1.

— , and — 2010: Using satellite altimetry to correct mean temperature and salinity fields derived from Argo floats in the ocean regions around Australia. Deep-Sea Res. I, 57, 11371151, https://doi.org/10.1016/j.dsr.2010.05.010.

— R. C. Coleman, R. J. Bailey, and P. Sutton, 2008: Decadal variability of East Australian Current transport inferred from repeated high-density XBT transects, a CTD survey and satellite altimetry. J. Geophys. Res., 113, C08039, https://doi.org/ 10.1029/2007JC004664.

Riser, S. C., and Coauthors, 2016: Fifteen years of ocean observations with the global Argo array. Nat. Climate Change, 6, 145153, https://doi.org/10.1038/nclimate2872. 
Roemmich, D., and J. Gilson, 2009: The 2004-2008 mean and annual cycle of temperature, salinity, and steric height in the global ocean from the Argo Program. Prog. Oceanogr., 82, $81-$ 100, https://doi.org/10.1016/j.pocean.2009.03.004.

— , and Coauthors, 2010: Integrating the ocean observing system: Mobile platforms. Proceedings of OceanObs'09: Sustained Ocean Observations and Information for Society, J. Hall, D. E. Harrison, and D. Stammer, Eds., Vol. 1, ESA Publ. WPP-306, https://doi.org/10.5270/OceanObs09.pp.33.

Schönau, M. C., D. L. Rudnick, I. Cerovecki, G. Gopalakrishnan, B. D. Cornuelle, J. L. McClean, and B. Qiu, 2015: The Mindanao Current: Mean structure and connectivity. Oceanography, 28 (4), 34-45, https://doi.org/10.5670/oceanog.2015.79.

Send, U., and Coauthors, 2010: A global boundary current circulation observing network. Proceedings of OceanObs'09: Sustained Ocean Observations and Information for Society, J. Hall, D. E. Harrison, and D. Stammer, Eds., Vol. 2, ESA Publ. WPP-306, https://doi.org/10.5270/OceanObs09.cwp.78.

Sloyan, B. M., K. R. Ridgway, and R. Cowley, 2016: The East Australian Current and property transport at $27^{\circ} \mathrm{S}$ from 2012 to 2013. J. Phys. Oceanogr., 46, 993-1008, https://doi.org/ 10.1175/JPO-D-15-0052.1.

Smith, W. H. F., and D. T. Sandwell, 1997: Global sea floor topography from satellite altimetry and ship depth soundings. Science, 277, 1956-1962, https://doi.org/10.1126/science. 277.5334.1956.

Talley, L. D., 2008: Freshwater transport estimates and the global overturning circulation: Shallow, deep and throughflow components. Prog. Oceanogr., 78, 257-303, https://doi.org/10.1016/ j.pocean.2008.05.001.
Tilburg, C. E., H. E. Hurlburt, J. J. O'Brien, and J. F. Shriver, 2001: The dynamics of the East Australian Current system: The Tasman Front, the East Auckland Current, and the East Cape Current. J. Phys. Oceanogr., 31, 2917-2943, https://doi.org/ 10.1175/1520-0485(2001)031<2917:TDOTEA>2.0.CO;2.

van der Linden, W. J. M., 1970: Morphology of the Tasman sea floor. N. Z. J. Geol. Geophys., 13, 282-291, https://doi.org/ 10.1080/00288306.1970.10428218.

van Sebille, E., L. M. Beal, and A. Biastoch, 2010: Sea surface slope as a proxy for Agulhas Current strength. Geophys. Res. Lett., 37, L09610, https://doi.org/10.1029/2010GL042847.

Wood, J. E., A. Schaeffer, M. Roughan, and P. M. Tate, 2016: Seasonal variability in the continental shelf waters off southeastern Australia: Fact or fiction? Cont. Shelf Res., 112, 92103, https://doi.org/10.1016/j.csr.2015.11.006.

Yang, Y. J., and Coauthors, 2015: Mean structure and fluctuations of the Kuroshio East of Taiwan from in situ and remote observations. Oceanography, 28 (4), 74-83, https://doi.org/ 10.5670/oceanog.2015.83.

Zilberman, N. V., D. H. Roemmich, and S. T. Gille, 2013: The mean and the time variability of the shallow meridional overturning circulation in the tropical South Pacific Ocean. J. Climate, 26, 4069-4087, https://doi.org/10.1175/JCLI-D-12-00120.1.

, and - 2014: Meridional volume transport in the South Pacific: Mean and SAM-related variability. J. Geophys. Res. Oceans, 119, 2658-2678, https://doi.org/10.1002/2013JC009688. , _ _ and _ 2017: The East Pacific Rise current: Topographic enhancement of the interior flow in the South Pacific Ocean. Geophys. Res. Lett., 44, 277-285, https://doi.org/ 10.1002/2016GL069039. 